\title{
Laboratory investigation into the compressive strength of cemented paste tailings aggregate fills
}

\author{
I Hane University of Quebec, Canada \\ T Belem University of Quebec, Canada \\ M Benzaazoua University of Quebec, Canada
}

A Maqsoud University of Quebec, Canada

\begin{abstract}
The use of backfill has now become a component of underground mining operations. In terms of mining methods, the top-down method would be less expensive than the bottom-up method, irrespective of the rock mass hardness. However, the implementation of the top-down method requires a high compressive strength ( $4 \mathrm{MPa}$ ) of backfill. The addition of aggregates (e.g. crushed waste rock) to the tailings could achieve this targeted strength. This paper investigates the effect of adding aggregates (crushed waste rock) on the compressive strength development of cemented paste tailings aggregate fill (PAF). Two types of waste rock were crushed to two aggregate sizes $(0 / 10$ and $0 / 15 \mathrm{~mm})$ and their proportion in PAF mixtures varied from 10 to $50 \% \mathrm{v} / \mathrm{v}$ (by cumulative volume of dry crushed waste rock and tailings). These are oxidised acid generating waste rocks (AG) and non-acid generating waste rocks (NAG). The binder type used is a blend of 20\% general use Portland cement (type GU) and $80 \%$ of ground granulated blast furnace slag (GBFS) at 5 wt\% (by total dry mass of aggregates and tailings). The unconfined compressive strength was determined at seven, 28 and 90 days of curing. The results show that the addition of crushed development waste rock to the cemented paste backfill increases significantly its compressive strength. The strength gain varies in the range $28-93 \%$ at 28 days and $5-44 \%$ at 90 days of curing in drained conditions. However, the strength development is influenced by the aggregate class of size, the volume and the mineralogy of the aggregates in the mixture.
\end{abstract}

Keywords: tailings, crushed waste rock, aggregate, paste aggregate fill (PAF), compressive strength

\section{Introduction}

The mining industry generates a significant amount of wastes; the most important of them are waste rocks and tailings (Amaratunga 1991; Aubertin et al. 2002). Storing these wastes on surface storing facilities often leads to environmental problems. Indeed, sulphurous wastes, once exposed to the air and in the presence of water, produce acid mine drainage (AMD). One way of managing these mine wastes is by preparing cemented paste backfill (CPB), which is a mixture of tailings, mixing water and a binding agent (Grice 1998; Benzaazoua et al. 1999, 2002, 2004; Belem et al. 2000; Aubertin et al. 2002; Kesimal et al. 2002; Yilmaz et al. 2009; Abdul-Hussain \& Fall 2011; Tariq \& Yanful 2013; Hane et al. 2017). The primary role of paste backfill is to contribute to ground control (Mitchell et al. 1982; Lun 1986; Benzaazoua et al. 1999; Bernier et al. 1999; Belem et al. 2002; Dorricott \& Grice 2002; De Souza et al. 2003; Kesimal et al. 2004; Belem \& Benzaazoua 2008; Belem 2009; Yilmaz et al. 2014) by playing the role of secondary mine support. The secondary role of underground paste backfill is to reduce the environmental impacts of mining activities by reducing the amount of tailings to be stored in tailings storage facilities (Grice \& Street, 1998; Aubertin et al. 2002; Benzaazoua et al. 2002; Kesimal et al. 2002; Yilmaz et al. 2009; Abdul-Hussain \& Fall 2011; Tariq \& Yanful 2013). 
Cemented paste backfill is the most used backfill in the mining industry, but mixed backfill is increasingly used (Leahy \& Cowling 1978; Arioglu 1984; Yu \& Counter 1983; Swan 1985; Lun 1986; Grice 1998; Senyur \& Erer 1989; Farsangi et al. 1996; Annor 1999; Wang \& Villaescusa 2000; O'Toole 2004; Kintzel 2005; Hane et al. 2017). As mines get deeper it is important to produce a backfill with improved mechanical properties compared to conventional $\mathrm{CPB}$ in order to enhance ground control and maximise ore recovery.

The main objective of this paper is to present the mechanical characteristics of cemented tailings paste aggregate fill (PAF), which is one type of mixed backfill composed of tailings, crushed waste rocks (aggregates), mixing water and a binding agent. Two types of waste rock were used: oxidised and acid generating waste rocks (AG) and non-acid generating waste rocks (NAG). The waste rocks were crushed to two different classes of size: $0 / 10$ and $0 / 15 \mathrm{~mm}$. The proportion of aggregates in the PAF mixtures is varied from 10 to $50 \% \mathrm{v} / \mathrm{v}$ by volume (or 8 to $45 \% \mathrm{~m} / \mathrm{m}$ by dry mass) of both dry aggregates and tailings. The binder type used is a blend of $20 \%$ general use Portland cement (type GU) and $80 \%$ ground granulated blast furnace slag (GBFS). The binder content was $5 \% \mathrm{~m} / \mathrm{m}$ by dry mass of aggregates and tailings. Figure 1 illustrates the different ingredients of cemented paste tailings aggregate fill and the factors that can affect their performance.

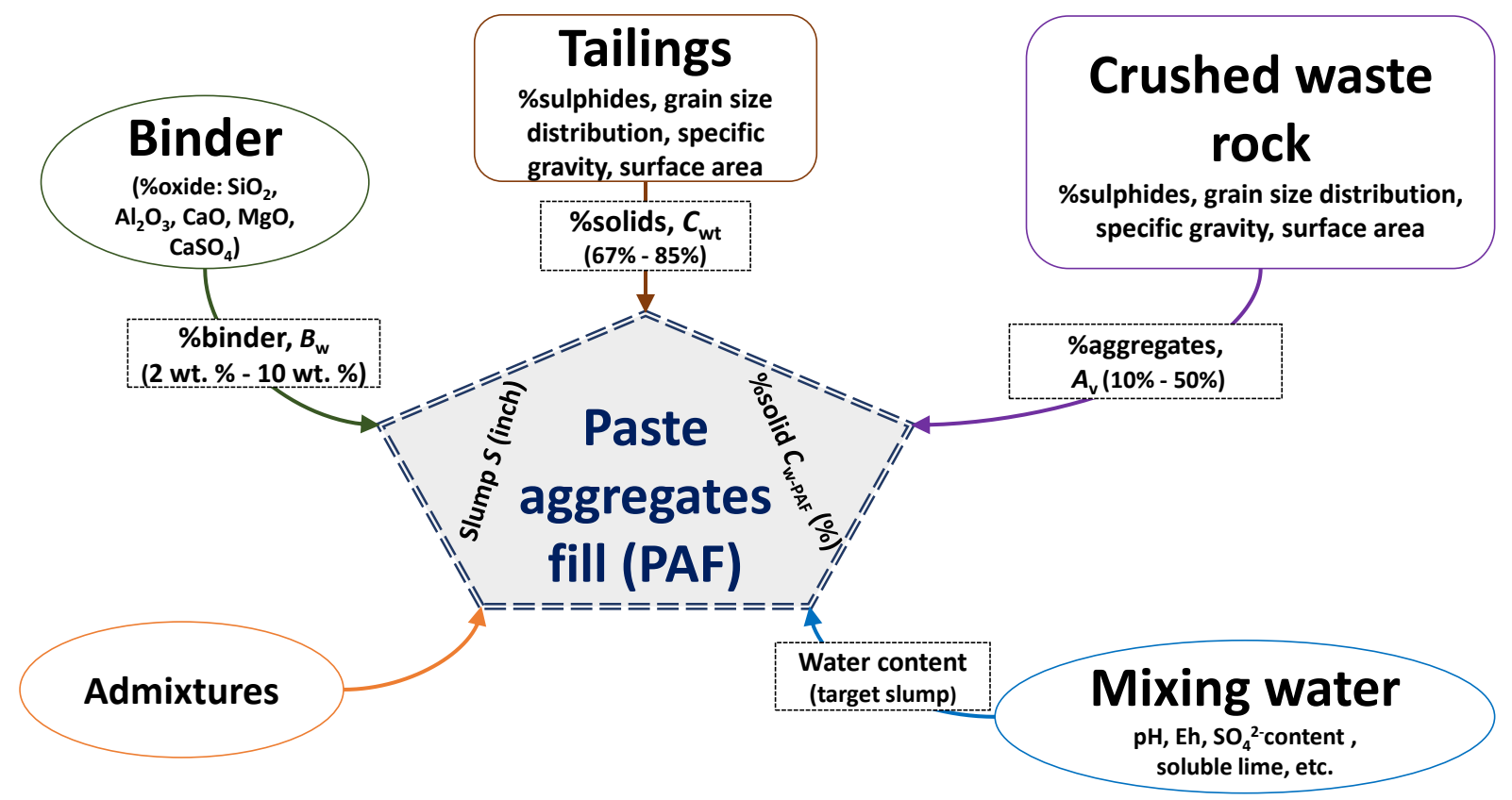

Figure 1 Different components of PAF and the factors that can affect their performance (Hane et al. 2017)

\section{$2 \quad$ Materials and methods}

\subsection{Tailings and waste rocks samples}

The waste rocks and tailings used in this paper were sampled from LaRonde mine (Quebec, Canada). The waste rocks were crushed before their use. They were homogenised and a representative amount of samples was oven-dried and finely ground to conduct chemical and mineralogical analyses. The crushed waste rocks were then sieved in order to get two classes of aggregates size of $0 / 15$ and $0 / 10 \mathrm{~mm}$. The tailings were also homogenised and their chemical, mineralogical and physical characteristics were determined. Figure 2 shows the grain size distribution of tailings and aggregates. Table 1 summarises the physical properties of tailings and aggregates. 

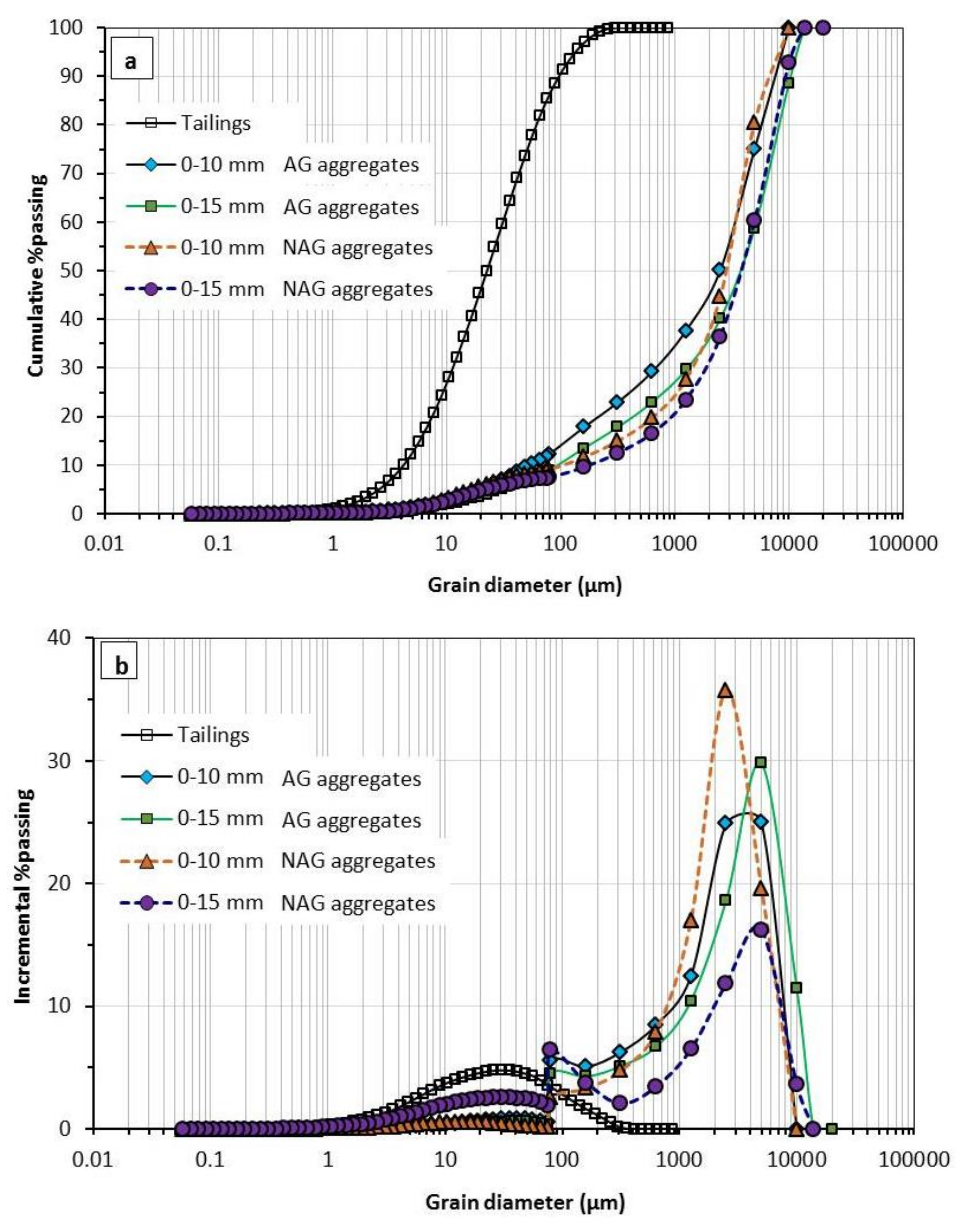

Figure 2 Grain size distributions of tailings and crushed waste rocks AG and NAG aggregates: (a) Cumulative curves; and, (b) Histograms

Table 1 Physical properties of tailings and aggregates

\begin{tabular}{lllllll}
\hline \multirow{2}{*}{ Parameters } & \multirow{2}{*}{ Unit } & Tailings & \multicolumn{3}{c}{ Aggregates AG } & \multicolumn{2}{c}{ Aggregates NAG } \\
\cline { 4 - 8 } & & & $\mathbf{0 / 1 5} \mathbf{~ m m}$ & $\mathbf{0 / 1 0} \mathbf{~ m m}$ & $\mathbf{0 / 1 5} \mathbf{~ m m}$ & $\mathbf{0 / 1 0 ~} \mathbf{~ m}$ \\
\hline Specific gravity $(G s)$ & - & 3.42 & 2.89 & 2.89 & 2.80 & 2.80 \\
Surface area $\left(\mathrm{S}_{\mathrm{s})}\right.$ & $\mathrm{m}^{2} / \mathrm{g}$ & 2.898 & - & - & - & - \\
$\mathrm{C}_{U}=\mathrm{D}_{60} / \mathrm{D}_{10}$ & - & 7.44 & 52.6 & 66 & 27.0 & 33.5 \\
$\mathrm{C}_{\mathrm{C}}=\mathrm{D}_{30}{ }^{2} /\left(\mathrm{D}_{60}{ }^{*} \mathrm{D}_{10}\right)$ & - & 1.0 & 3.6 & 3.0 & 4.1 & 6.7 \\
$\mathrm{D}_{10}$ & $\mu \mathrm{m}$ & 4.2 & 95.0 & 50.0 & 185.0 & 100.0 \\
$\mathrm{D}_{30}$ & $\mu \mathrm{m}$ & 11.3 & 1.3 & 700.0 & 2.0 & 1.5 \\
$\mathrm{D}_{50}$ & $\mu \mathrm{m}$ & 22.5 & 3.8 & 2.5 & 4.0 & 2.9 \\
$\mathrm{D}_{60}$ & $\mu \mathrm{m}$ & 31.0 & 5.0 & 3.3 & 5.0 & 3.4 \\
$D_{90}$ & $\mu \mathrm{m}$ & 96.8 & 10.0 & 7.7 & 8.2 & 6.6 \\
Ultrafines $\left(\mathrm{P}_{20 \mu \mathrm{m}}\right)$ & - & $46 \%$ & - & - & - & - \\
\hline
\end{tabular}


The specific gravity $G_{s}\left(=\rho_{s} / \rho_{w}\right)$ of tailings and aggregates was determined using a helium pycnometer 1330 AccuPyc Micromeritics ${ }^{\circledR}$ in accordance with ASTM C128 standard (ASTM International 2015). The specific density $\rho_{\mathrm{s}}$ was determined to be $3.42 \mathrm{~g} / \mathrm{cm}^{3}$ for tailings, $2.89 \mathrm{~g} / \mathrm{cm}^{3}$ for oxidised and acid generating aggregates (AG) and $2.80 \mathrm{~g} / \mathrm{cm}^{3}$ for non-acid generating aggregates (NAG). The specific surface area $\mathrm{S}_{\mathrm{s}}$ for the tailings was determined to be $2.898 \mathrm{~m}^{2} / \mathrm{kg}$.

The grain size distribution (GSD) of aggregates was performed using sieving method ( $d_{\text {aggregates }}>80 \mu \mathrm{m}$ ) and a Malvern ${ }^{\circledR}$ Mastersizer $S 2000$ laser particle size analyser $\left(d_{\text {aggregates }} \leq 80 \mu \mathrm{m}\right)$. The GSD of aggregates is a combination of coarse and fine aggregates. The comparison of the results in Figure 2 shows that the aggregates AG (acid generating sample) contain more fine particles than the aggregates NAG (non-acid generating sample).

This figure also shows that the aggregates exhibit a spreading sizes $\left(20<C_{u}<200\right.$, and $C_{u}=$ coefficient of uniformity). It can be seen that the tailings sample is similar and typical of tailings samples from hard-rock mines. The percentage of ultrafine particles $(d<20 \mu \mathrm{m}), \mathrm{P}_{20 \mu \mathrm{m}}$ is $46 \%$, which put these tailings as medium size tailings (Landriault et al. 1997).

Table 2 summarises results of the mineralogical composition of tailings which is dominated by quartz (43.0 wt.\%) and pyrite (32.9 wt.\%). Aggregates AG (oxidised) have a high content in albite $(24.0 \%)$ and quartz (31.7\%). Most part of aggregates NAG (non-oxidised) is composed of quartz (50.8 wt.\%) and muscovite $(28.8 \%)$, with low sulphide content ( 0.8 wt.\% of pyrite).

Table 2 Mineralogical composition of tailings and aggregates

\begin{tabular}{llll}
\hline \multirow{2}{*}{ Mineral } & \multicolumn{3}{c}{ Grade (wt.\%) } \\
\cline { 2 - 4 } & Tailings & Aggregates AG & Aggregates NAG \\
\hline Quartz & 43.0 & 31.7 & 50.8 \\
Pyrite & 32.9 & 1.7 & 0.8 \\
Albite & 9.6 & 24.0 & 3.4 \\
Muscovite & 3.9 & 8.1 & 28.8 \\
Gypsum & 2.4 & 6.0 & - \\
Chlorite Ilb & 8.2 & 11.1 & 3.6 \\
Actinolite & - & 17.4 & - \\
Dolomite & - & - & 10.6 \\
Calcite & - & - & 2.0 \\
\hline
\end{tabular}


The main chemical composition of tailings and aggregates (Table 3 ) shows that tailings are rich in iron (21.2\%) and sulphur (20.2\%), while aggregates AG (oxidised) are dominated by silica (21.8\%), titanium (10.4\%) and iron (7.9\%). Aggregates NAG (non-oxidised) contain silica as major element (25.8\%) with low sulphur $(0.8 \%)$.

Table 3 Chemical composition of tailings and aggregates

\begin{tabular}{|c|c|c|c|c|}
\hline Elements & Unit & Tailings & Aggregates AG & Aggregates NAG \\
\hline $\mathrm{Si}$ & $\% *$ & 15.1 & 21.8 & 25.8 \\
\hline Al & $\%$ & 1.5 & 7.0 & 6.2 \\
\hline $\mathrm{Ca}$ & $\%$ & 0.1 & 4.8 & 2.8 \\
\hline $\mathrm{Fe}$ & $\%$ & 21.2 & 7.9 & 3.8 \\
\hline K & $\%$ & 0.6 & 1.0 & 2.5 \\
\hline $\mathrm{Mg}$ & $\%$ & 0.1 & 0.9 & 0.8 \\
\hline $\mathrm{Na}$ & $\%$ & 0.4 & 1.5 & 0.3 \\
\hline$S$ & $\%$ & 20.2 & 2.6 & 0.8 \\
\hline As & $\mathrm{mg} / \mathrm{kg}^{* *}$ & 155.0 & 23.0 & $<5$ \\
\hline $\mathrm{Ba}$ & $\mathrm{mg} / \mathrm{kg}$ & 166.0 & 516.0 & 293.0 \\
\hline $\mathrm{Bi}$ & $\mathrm{mg} / \mathrm{kg}$ & 195.0 & 14.0 & 73.0 \\
\hline Co & $\mathrm{mg} / \mathrm{kg}$ & 58.0 & 47.0 & 26.0 \\
\hline $\mathrm{Cr}$ & $\mathrm{mg} / \mathrm{kg}$ & 190.0 & 1.6 & 280.0 \\
\hline $\mathrm{Cu}$ & $\mathrm{mg} / \mathrm{kg}$ & 482.0 & 459.0 & 29.0 \\
\hline $\mathrm{Mn}$ & $\mathrm{mg} / \mathrm{kg}$ & 126 & 1.048 & 1265 \\
\hline Mo & $\mathrm{mg} / \mathrm{kg}$ & 23.0 & 51.0 & 26.0 \\
\hline $\mathrm{Ni}$ & $\mathrm{mg} / \mathrm{kg}$ & 70.0 & 481.0 & 123.0 \\
\hline $\mathrm{Pb}$ & $\mathrm{mg} / \mathrm{kg}$ & 941.0 & 91.0 & 119.0 \\
\hline $\mathrm{Ti}$ & $\mathrm{mg} / \mathrm{kg}$ & 6334.0 & 10.4 & 9.3 \\
\hline $\mathrm{Zn}$ & $\mathrm{mg} / \mathrm{kg}$ & 1.6 & 480.0 & $<5$ \\
\hline Total & & 100 & 99.99 & 100 \\
\hline
\end{tabular}

*Determined using chemical composition (XRF) (in \%).

**Determined using an ICP-AES (in $\mathrm{mg} / \mathrm{kg}$ ).

\subsection{Binding agent}

The blended binder GU-GBFS (20\% of Portland cement type GU and $80 \%$ of ground blast furnace slag - GBFS or slag) was used. The binder content was $5 \%$ by dry mass of tailings and aggregates. Table 4 shows the chemical composition of the binding agent. It is composed mainly of calcium oxide (46\%) and silicon oxide (27\%). 
Table 4 Chemical composition (XRF) of the binding agents (wt.\%)

\begin{tabular}{llll}
\hline $\begin{array}{l}\text { Chemical } \\
\text { composition }\end{array}$ & $\begin{array}{l}\text { Portland } \\
\text { cement GU }\end{array}$ & $\begin{array}{l}\text { Ground blast } \\
\text { furnace slag }\end{array}$ & $\begin{array}{l}\text { Blended binder } \\
\text { GU-slag (20-80 \%) }\end{array}$ \\
\hline $\mathrm{Al}_{2} \mathrm{O}_{3}$ & 5.14 & 9.86 & 8.92 \\
$\mathrm{CaO}$ & 67.80 & 40.56 & 46.01 \\
$\mathrm{Fe}_{2} \mathrm{O}_{3}$ & 3.40 & 0.04 & 0.71 \\
$\mathrm{~K}_{2} \mathrm{O}$ & 1.06 & 0.52 & 0.63 \\
$\mathrm{MgO}$ & 2.19 & 9.92 & 8.37 \\
$\mathrm{MnO}$ & 0.04 & 0.48 & 0.39 \\
$\mathrm{Na}_{2} \mathrm{O}$ & 0.84 & 0.81 & 0.82 \\
$\mathrm{SO}_{3}$ & 6.24 & 4.74 & 5.04 \\
$\mathrm{SiO}_{2}$ & 16.60 & 29.93 & 27.26 \\
\hline
\end{tabular}

\subsection{Mixing water}

Municipal tap water was used for the PAF mixtures preparation. Table 5 summarises the chemical composition of the mixing water. It can be observed that the tap water contains less sulphate $(66.21 \mathrm{mg} / \mathrm{L})$ and calcium $(25.7 \mathrm{mg} / \mathrm{L})$ than the tailings pore water.

Table 5 Geochemical and chemical analyses of the mixing water

\begin{tabular}{|c|c|c|}
\hline \multirow{2}{*}{ Parameter } & \multicolumn{2}{|c|}{ Value } \\
\hline & Tailings pore water & Tap water \\
\hline $\mathrm{pH}$ & 7.97 & 7.9 \\
\hline Eh $(m V)$ & n.d. & 674 \\
\hline Conductivity $(\mu \mathrm{S} / \mathrm{cm})$ & 9.175 & 212 \\
\hline Elements & \multicolumn{2}{|c|}{ Concentration (mg/L) } \\
\hline Al & 0.026 & 0.046 \\
\hline $\mathrm{Ca}$ & 527 & 25.7 \\
\hline $\mathrm{Mg}$ & 3.76 & 3.27 \\
\hline $\mathrm{Ba}$ & 0.041 & 0.009 \\
\hline $\mathrm{Cu}$ & 0.072 & 0.099 \\
\hline $\mathrm{Fe}$ & 0.043 & 0.027 \\
\hline $\mathrm{Mn}$ & 0.032 & 0.005 \\
\hline $\mathrm{Ni}$ & 0.005 & 0.005 \\
\hline $\mathrm{Zn}$ & 0.016 & 0.183 \\
\hline $\mathrm{S}_{\text {tot }}$ & 1.750 & 22.1 \\
\hline $\mathrm{SO}_{4}{ }^{2-}$ & 5.243 & 66.21 \\
\hline $\mathrm{Si}$ & 1.70 & 1.68 \\
\hline
\end{tabular}




\subsection{Paste aggregates fill mixtures preparation and curing}

As previously mentioned, two types of waste rocks were used; namely oxidised waste rocks (aggregates $A G)$ and non-oxidised and non-acid generating waste rocks (aggregates NAG). These waste rocks were crushed to two classes of size $(0 / 10 \mathrm{~mm}$ and $0 / 15)$ and their proportion in PAF mixtures varied from 10 to $50 \% \mathrm{v} / \mathrm{v}$ (by volume of dry waste rocks and tailings). The mixtures were prepared according to a fixed slump of 7" (178 mm).

The paste aggregates fill mixtures were then poured into 4" $(10 \mathrm{~cm})$ diameter and 8 " $(20 \mathrm{~cm})$ height plastic moulds, capped and stored in a humid chamber at a controlled temperature of $25 \pm 2^{\circ} \mathrm{C}$ and under a relative humidity $\mathrm{RH} \geq 90 \%$. At each curing time (seven, 14,28 and 90 days), PAF specimens were subjected to the uniaxial compression tests.

Figure 3 presents the variation in the solid mass concentration for different PAF mixtures for achieving a constant slump of about $178 \mathrm{~mm}$ or 7" (the average slump value was 7.03" with a standard deviation of 0.07 ; i.e. $7.03 \pm 0.07$ "). It can be observed that the increase in the proportion of aggregates leads to an increase in the solid mass concentration of the mixture. Thus, the solid mass concentration increased from $77 \%$ (control mixtures without aggregates) to $83 \%$ (mixtures containing $50 \% \mathrm{v} / \mathrm{v}$ of aggregates). Since the binder dosage of $5 \%$ is by dry mass of tailings and aggregates, this will necessarily lead to a reduction in the water-to-binder ratio.

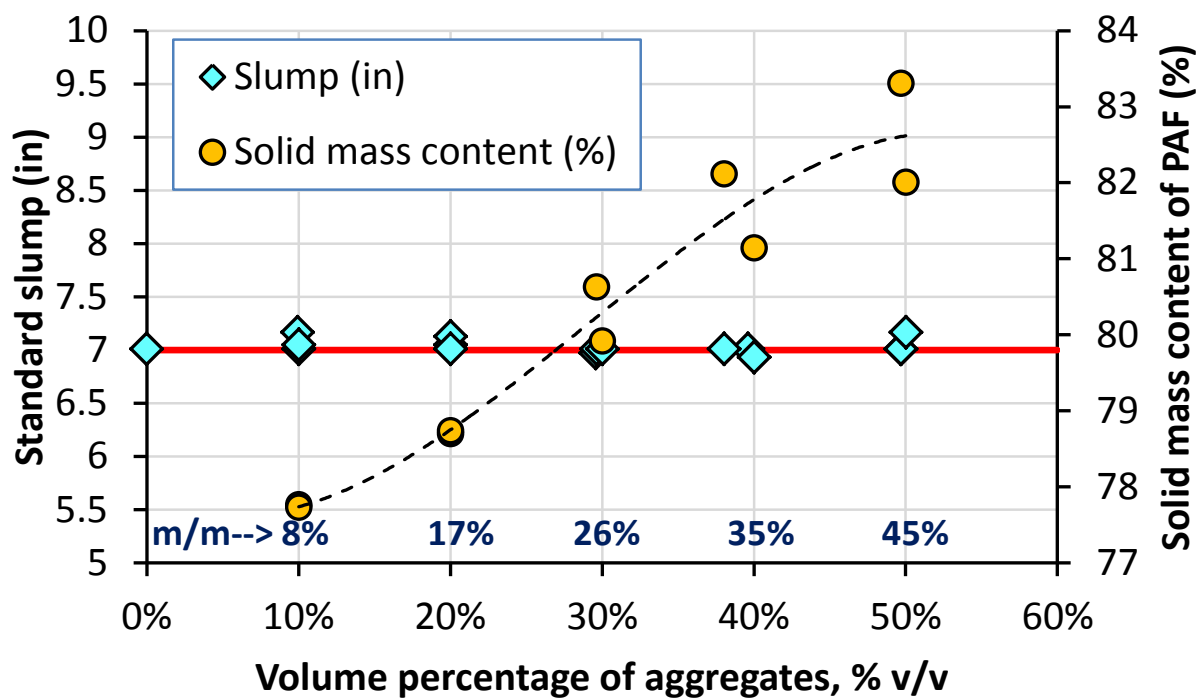

Figure 3 Variation in PAF solid mass concentration as a function of aggregates volume content and for the three classes of aggregate gradation $(0 / 10$ and $0 / 15 \mathrm{~mm})$

\subsection{Uniaxial compression tests}

The mechanical characterisation of paste aggregates fill was based only on the uniaxial compressive strength (UCS) determined from uniaxial compression tests in accordance with ASTM C39 standards (ASTM International 2017). The UCS test consists of placing a PAF sample between two platens of the MTS 10/GL press machine and by applying a vertical load until the sample breaks (Figure 4(a)). Three curing times were tested: seven, 28 and 91 days and each UCS value was obtained from the average of three tests (triplicate). Figure 4 (b) presents the internal view of PAF after breaking. 

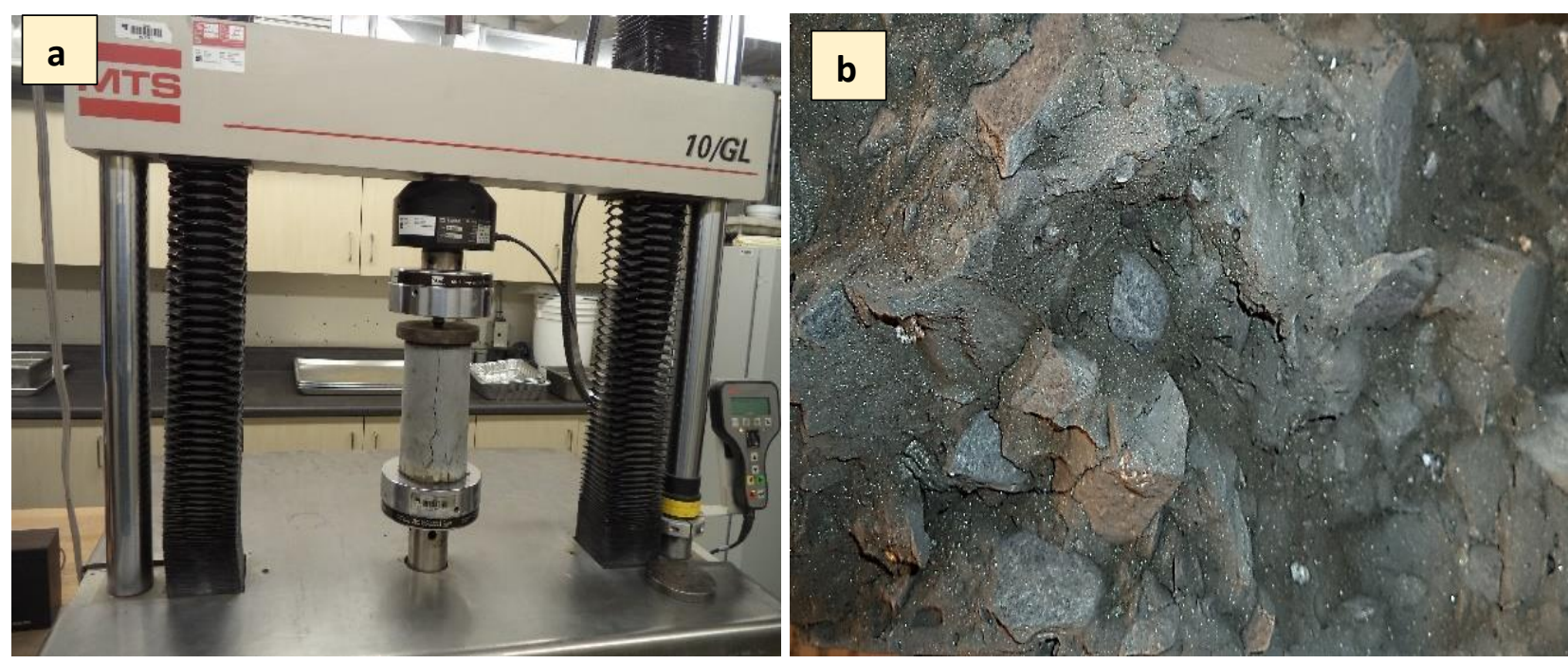

Figure 4 Uniaxial compression tests; (a) Specimen between the platens of the MTS 10/GL press; and, (b) Close-up of paste aggregate fill fracture plane after breakage

\section{Results and discussion}

The variation in UCS values of PAF specimens as a function of curing time and for the two types of aggregates used (AG and NAG), the aggregates volume contents $(10,20,30,40$ and $50 \% \mathrm{v} / \mathrm{v})$ and the two classes of size gradation (0/10 and $0 / 15)$ is shown in Figure 5. From this figure, it can be observed that at 28 days of curing time, all PAF mixtures containing aggregates NAG developed higher strength (UCS) compared to the PAF containing aggregates AG. The PAF strength tends to increase with the increase in the proportion of aggregates volume. It can also be observed that the UCS value generally increases as the aggregate size increases. The volumetric fractional replacement of tailings by aggregates has modified the grain size distribution of the composite skeleton by increasing its coarse fraction. Previous works have shown better strength development with coarse to medium grained materials depending on the binder type used (Annor 1999; Benzaazoua et al. 2004; Fall et al. 2005).

At 91 days of curing time (i.e. long-term) a similar compressive strength was developed when using $50 \% \mathrm{v} / \mathrm{v}$ of $0 / 15 \mathrm{~mm}$ class of size for aggregates $A G(U C S \sim 4 \mathrm{MPa}$ ) and aggregates NAG (UCS $\sim 4 \mathrm{MPa}$ ) and of $0 / 10 \mathrm{~mm}$ class of size for aggregates $A G$ (UCS $\sim 4 \mathrm{MPa}$ ) only.

The results also indicate that the higher strength was developed with the addition of $40 \% \mathrm{v} / \mathrm{v}$ for class of size $0 / 10 \mathrm{~mm}$ of aggregates NAG. The highest UCS was reached with the addition of $50 \% \mathrm{v} / \mathrm{v}$ for class of size $0 / 15 \mathrm{~mm}$ of aggregates $A G$ and NAG, and for class of size $0 / 10 \mathrm{~mm}$ of aggregates $A G$ (oxidised waste rocks).

However, it should be noted that the hardening (and/or binder hydration) of the PAF mixtures containing aggregates NAG (non-acid generating) is much faster. Indeed, at 28 days of curing, the PAF specimens containing $50 \% \mathrm{v} / \mathrm{v}$ of aggregates NAG reached 78 and $69 \%$ of the 91 day strength, respectively for $0 / 15$ and $0 / 10 \mathrm{~mm}$ classes of size. In contrast to the aggregates $A G$, the strength gain is 45 and $47 \%$ for $0 / 15$ and $0 / 10 \mathrm{~mm}$ classes of size.

Chemical and mineralogical analyses have shown that the waste rocks AG are potentially acid generating and that the waste rocks NAG are non-acid generating. Previous works (Benzaazoua et al. 1999, 2002; Kesimal et al. 2005) have shown that sulphates can inhibit the binder hydration reactions in cemented paste backfill mixtures and affect the mechanical strength development at short and long terms. 

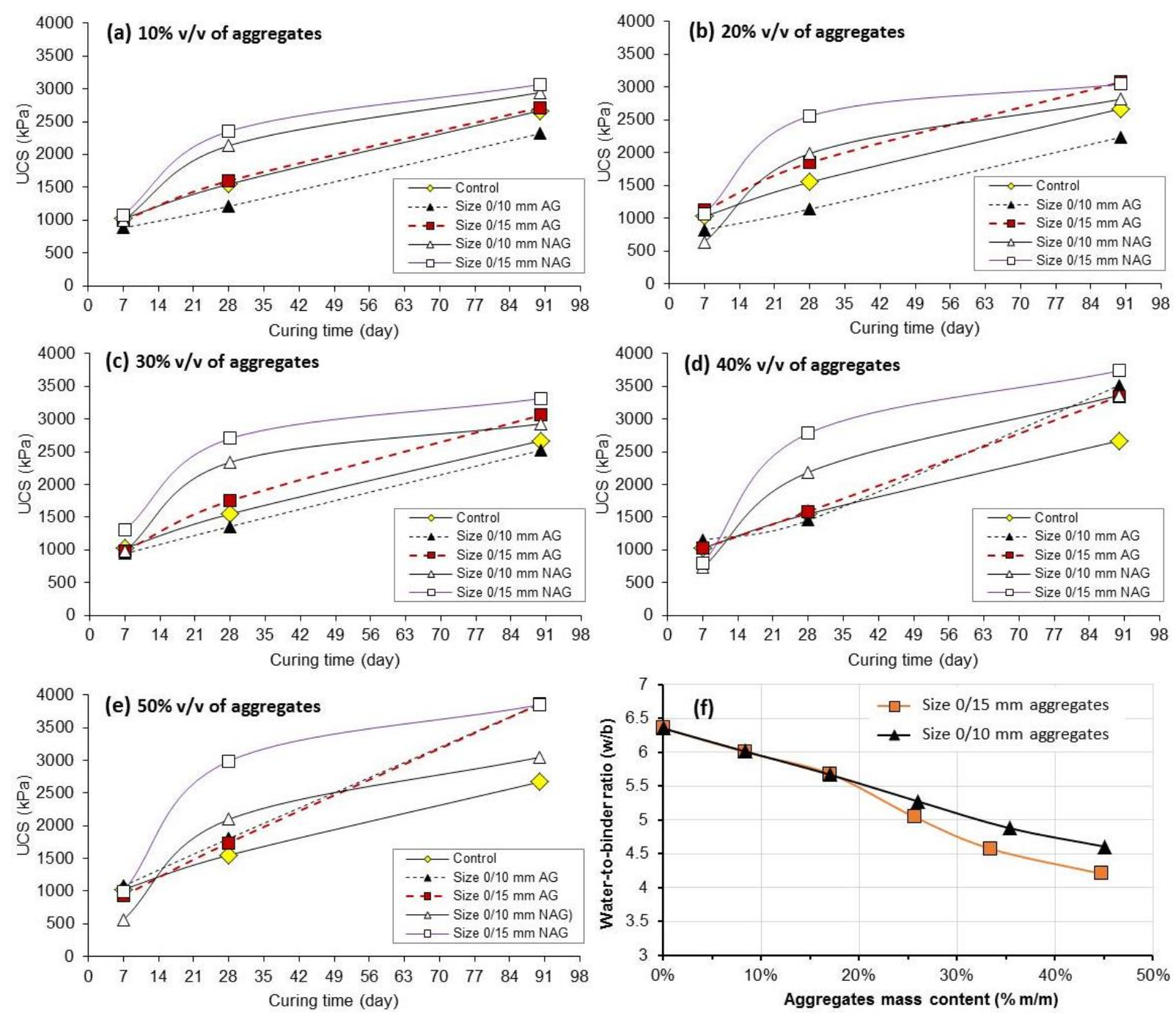

Figure 5 Variation in UCS as a function of curing time for PAF mixtures with aggregates AG and NAG; (a) $10 \% \mathrm{v} / \mathrm{v}$ of aggregates; (b) $20 \% \mathrm{v} / \mathrm{v}$ of aggregates; (c) $30 \% \mathrm{v} / \mathrm{v}$ of aggregates; (d) $40 \% \mathrm{v} / \mathrm{v}$ of aggregates; (e) $50 \% \mathrm{v} / \mathrm{v}$ of aggregates; and, (f) The water-to-binder ratio. Control $=\mathrm{CPB}$ without any aggregates addition

For aggregates $A G, 40 \%$ replacement is required for achieving a compressive strength higher than the control ( $0 \%$ aggregates). The presence of sulphates seems to inhibit the hardening process of PAF mixtures. For PAF mixtures exhibiting higher compressive strength than the control mixtures, the effect of sulphates is likely countered by the gradation effect of aggregates.

The effect of sulphates is sometimes beneficial in CPB when participating in hardening (Benzaazoua et al. 2002 , 2004). In the case of mixtures containing $50 \% \mathrm{v} / \mathrm{v}$ of aggregates $A G$, the sulphate content is much higher. Thus, these sulphates could participate within the PAF matrix, so that the strength development is similar to that developed when using $50 \% \mathrm{v} / \mathrm{v}$ of the PAF mixtures for class of size $0 / 15 \mathrm{~mm}$ of the aggregates $A G$ and NAG.

The UCS values of the PAF mixtures containing $50 \% \mathrm{v} / \mathrm{v}$ for the class of size $0 / 10 \mathrm{~mm}$ of aggregates AG is $26 \%$ higher than that obtained using the class of size $0 / 10 \mathrm{~mm}$ of aggregates NAG at 91 days curing time. Even if the waste rocks $A G$ are problematic (acid generating), their use at a high volumetric percentage seems to be beneficial, sometimes more advantageous than the non-generating waste rocks NAG.

One of the main reasons why the UCS increases with the increase in the percentage of aggregates is that the grain size distribution is modified, which promotes better drainage and particle packing (consolidation). Also, increasing the aggregates volume content in the PAF mixtures will reduce the water requirement for 
achieving the target slump of $178 \mathrm{~mm}\left(7^{\prime \prime}\right)$, therefore reducing the water-to-binder ratio $(\mathrm{w} / \mathrm{b})$. The $\mathrm{w} / \mathrm{b}$ ratio is so important that it controls the hardening process of cementitious materials. The compressive strength is inversely proportional to the $\mathrm{w} / \mathrm{b}$ ratio, hence the lower the $\mathrm{w} / \mathrm{b}$ and the higher the compressive strength (Benzaazoua et al. 2004; Wu et al. 2001; Kesimal et al. 2005).

\section{Conclusion}

This paper investigated the compressive strength properties of cemented PAF. Two types of waste rocks (acid generating AG and non-acid generating NAG) and two classes of aggregates size (crushed waste rocks) were tested as mine tailings replacement for PAF mixtures preparation. The replacement rate of aggregates was varied from 10 to $50 \% \mathrm{v} / \mathrm{v}$ of the total volume of tailings and aggregates. The unconfined compressive strength of these PAF mixtures was investigated at seven, 28 and 91 days of curing times. The results of this study show that:

- The PAFs prepared with the class of size $0 / 15 \mathrm{~mm}$ aggregates developed better strength than PAFs prepared with the class of size $0 / 10 \mathrm{~mm}$ at 28 days curing (short-term).

- At 28 days curing time, replacement of 10 to $50 \% \mathrm{v} / \mathrm{v}$ of tailings by aggregates of class of size $0 / 15 \mathrm{~mm}$ in the PAF mixtures increased the unconfined compressive strength value in the range 3-12\% for aggregates AG and 28-93\% for aggregates NAG.

- At 90 days of curing, the strength gain varies between 2 and $45 \%$ for aggregates AG and between 5 and $44 \%$ for aggregates NAG.

- The compressive strength of PAF mixtures containing 30,40 and $50 \% \mathrm{v} / \mathrm{v}$ of aggregates NAG obtained at 28 days of curing was higher than the compressive strength obtained at 91 days of curing time for control specimens (CPB without aggregates).

- The mineralogy of the aggregates AG has an influence on the compressive strength of the PAF. Indeed, this mineralogy seems to be harmful at seven and 28 days (short-term) of curing time but has a beneficial effect at 91 days of curing time.

\section{References}

Abdul-Hussain, N \& Fall, M 2011, 'Unsaturated hydraulic properties of cemented tailings backfill that contains sodium silicate', Engineering Geology, vol. 123, no. 4, pp. 288-301.

Amaratunga, LM 1991, 'Experimental evaluation of a novel concept of utilization and disposal of fine mill tailings as aggregates by agglomeration', Minerals Engineering, vol. 4, no. 7-11, pp. 1081-1090.

Annor, A 1999, A Study of the Characteristics and Behaviour of Composite Backfill Material, PhD thesis, McGill University, Montreal.

Arioglu, E 1984, 'Design aspects of cemented aggregate fill mixes for tungsten stoping operations', Mining Science and Technology, vol. 1, pp. 209-214.

ASTM International 2015, ASTM C128-15: Standard Test Method for Relative Density (Specific Gravity) and Absorption of Fine Aggregate, ASTM International, West Conshohocken.

ASTM International, 2017, ASTM C39 / C39M-17a: Standard Test Method for Compressive Strength of Cylindrical Concrete Specimens, ASTM International, West Conshohocken.

Aubertin, M, Bussière, M \& Bernier L 2002, Environnement et Gestion des Rejets Miniers, Presse Internationales Polytechnique, Montreal, CD-ROM.

Belem, T 2009, Développement d'une Méthode Intégré d'Analyse de Stabilité des Chantiers Miniers Remblayés, IRSST Report No R-622, pp. 1-97.

Belem, T \& Benzaazoua, M 2008, 'Design and application of underground mine paste backfill technology', Geotechnical and Geological Engineering, vol. 26, no. 2, p. 175.

Belem, T, Benzaazoua, M, Bussière, B \& Dagenais, AM, 2002, 'Effects of settlement and drainage on strength development within mine paste backfill', Proceedings of Tailings and Mine Waste Management '02, A.A. Balkema, Rotterdam, pp. 139-148.

Benzaazoua, M, Belem, T \& Bussière, B 2002, 'Chemical factors that influence the performance of mine sulphidic paste backfill', Cement and Concrete Research, vol. 32, no. 7, pp. 1133-1144.

Benzaazoua, M, Fall, M \& Belem T 2004, 'A contribution to understanding the hardening process of cemented pastefill', Minerals Engineering, vol. 17, no. 2, pp. 141-152.

Benzaazoua, M, Ouellet, J Servant, S, Newman, P \& Verburg, R 1999, 'Cementitious backfill with high sulfur content physical, chemical, and mineralogical characterization', Cement and Concrete Research, vol. 29, no. 5, pp 719-725. 
Bernier, LR, Li, MG \& Moerman, A 1999, 'Effects of tailings and binder geochemistry on the physical strength of paste backfill', in D Goldsack, N Belzile, P Yearwood \& G Hall (eds), Proceedings of Mining and the Environment II, Laurentian University, Sudbury, pp. 1113-1122.

De Souza, E, Archibald, JF \& Dirige, APE 2003, 'Economics and perspectives of underground backfill practices in Canadian mining', Proceedings of the 105th Annual General Meeting of the Canadian Institute of Mining, Metallurgy and Petroleum, Canadian Institute of Mining, Metallurgy and Petroleum, Westmount, $15 \mathrm{p}$.

Dorricott, MG \& Grice, TA 2002, 'Backfill-the environmentally friendly tailings disposal system', Proceedings of the International Conference on the Sustainable Processing of Minerals Green Processing 2002, Australasian Institute of Mining and Metallurgy, Melbourne, pp. 265-270.

Emad, MZ 2013, Dynamic Performance of Cemented Rockfill Under Blast-induced Vibrations, PhD thesis, McGill University, Montreal.

Fall, M, Benzaazoua, M \& Ouellet, S 2005, 'Experimental characterization of the influence of tailings fineness and density on the quality of cemented paste backfill', Minerals Engineering, vol. 18, no. 1, pp. 41-44.

Farsangi, PN, Hayward, AG \& Hassani, FP 1996, 'Consolidated rockfill optimization at Kidd Creek Mines', CIM Bulletin, vol. 89, no. 1001 , pp. 129-134.

Grice, TA 1998, 'Underground mining with backfill', Proceedings of 2nd Annual Summit - Mine Tailings Disposal Systems, Australasian Institute of Mining and Metallurgy, Melbourne, pp. 1-14.

Hane, I, Belem, T, Benzaazoua, M \& Maqsoud, A 2017, 'Laboratory characterization of cemented tailings paste containing crushed waste rocks for improved compressive strength development', Geotechnical and Geological Engineering, vol. 35, pp. 645-662.

Hassani, FP \& Archibald, J 1998, Mine Backfill, Canadian Institute of Mine, Metallurgy and Petroleum, Westmount, CD-ROM.

Kintzel, R 2005, 'CAF backfill of primary stopes at Callie Underground Mine', Proceedings of the Ninth Underground Operators' Conference, Australasian Institute of Mining and Metallurgy, Melbourne, pp. 151-171.

Kesimal, A, Yilmaz, E \& Ercikdi, B 2004, 'Environmental benefits by use of paste backfill technology for disposal of sulfide-bearing mine tailings', Proceedings of the 4th International Scientific Conference - Modern Management of Mine Producing, Geology and Environmental Protection, vol. 4, SGEM International Scientific GeoConference, Sofia, pp. 431-440.

Kesimal, A, Yilmaz, E, Ercikdi, B, Alp, I \& Deveci, H 2005, 'Effect of properties of tailings and binder on the short-and long-term strength and stability of cemented paste backfill', Materials Letters, vol. 59, no. 28, pp. 3703-3709.

Landriault, D, Verburg, R, Cincilla, W \& Welch, D 1997, Paste Technology for Underground Backfill and Surface Tailings Disposal Applications, short course notes in Canadian Institute of Mining and Metallurgy Technical Workshop held on 27 April 1997, Canadian Institute of Mining, Metallurgy and Petroleum, Westmount.

Leahy, FJ \& Cowling, R 1978, 'Stope fill developments at Mount Isa', Proceedings of the Twelfth Canadian Rock Mechanics Symposium on Mining with Backfill, Canadian Institute of Mining, Metallurgy and Petroleum, Westmount.

Lun, PTW 1986, 'Soil reinforcing technique in mine backfilling', International Journal of Mining and Geological Engineering, vol. 4, pp. 47-66.

Mitchell, RJ \& Wong, BC 1982, 'Behaviour of cemented tailings sands', Canadian Geotechnical Journal, vol. 19, pp. 289-295.

O'Toole, D 2004, 'Features the basics of mine backfill: A review of some critical factors for Cement Aggregate Fill', Engineering and Mining Journal.

Senyur, G \& Dincer E 1989, 'Cement stabilized aggregate: Analyse of the proprieties related to curing time', International Journal of Mining Science and Technology, vol. 10, pp. 315-321.

Swan, G 1985, 'A new approach to cemented backfill design', CIM Bulletin, vol. 78, pp. 53-58.

Tariq, A \& Yanful, EK 2013, 'A review of binders used in cemented paste tailings for underground and surface disposal practices', Journal of Environmental Management, vol. 131, pp. 138-149.

Wang, C \& Villaescusa, E 2000, 'Backfill research at the Western Australian School of Mines', Proceedings of MassMin 2000, Australasian Institute of Mining and Metallurgy, Melbourne, pp. 1-15.

Wu, KR, Chen, B, Yao, W \& Zhang, D 2001, 'Effect of coarse aggregate type on mechanical properties of High-Performance Concrete', Cement and Concrete Research, vol. 31, pp. 1421-1425.

Yilmaz, E, Belem, T \& Benzaazoua, M 2014, 'Effects of curing and stress conditions on hydromechanical, geotechnical and geochemical properties of cemented paste backfill', Engineering Geology, vol. 168, pp. 23-37.

Yilmaz, E, Benzaazoua, M, Belem, T \& Bussière, B 2009, 'Effect of curing under pressure on compressive strength development of cemented paste backfill', Minerals Engineering, vol. 22, no. 9-10, pp. 772-785.

Yu, TR \& Counter, DB 1983, 'Backfill practice and technology at Kidd Creek Mines', CIM Bulletin, vol. 76, no. 856, pp. 56-65. 
